\title{
CITIZEN PARTICIPATION AND LOCAL PUBLIC MANAGEMENT THE CASE OF MUNICIPAL ENVIRONMENTAL COUNCILS IN BRAZIL
}

\author{
Biancca Scarpeline de Castro \\ Federal Rural University of Rio de Janeiro, Brazil \\ bianccastro2@gmail.com \\ Lucas de Almeida Nogueira da Costa \\ Federal University of Rio de Janeiro, Brazil \\ lucas.an.costa@gmail.com \\ Carlos Eduardo Frickmann Young \\ Federal University of Rio de Janeiro, Brazil \\ carloseduardoyoung@gmail.com
}

\begin{abstract}
This article examines whether citizen participation in environmental management through Brazil's Municipal Environmental Councils affects the municipal government's performance in terms of its expenditure on environmental management and capacity to obtain funds through the ICMS-E, a legal instrument that increases tax revenues for municipal governments with a better environmental performance. Based on analysis of data from the public budget and the characteristics of the Municipal Environmental Councils, it concludes that the existence of an Environmental Council positively affects municipal environmental management. Expenditure on the environmental management function and transfers from the ICMS-E tend to be higher in municipalities where there is an Environmental Council. This implies that social participation, through the Councils, positively affects municipal environmental management and helps to improve the municipal government's financial capacity.
\end{abstract}

Keywords: Public participation, Municipal-level councils, Environmental policy, Brazil. 


\section{PARTICIPACIÓN CIUDADANA Y GESTIÓN PÚBLICA LOCAL EL CASO DE LOS CONSEJOS AMBIENTALES MUNICIPALES EN BRASIL}

\section{RESUMEN}

El artículo analiza si la participación ciudadana en la gestión ambiental en Brasil, a través de los consejos ambientales municipales, afecta el desempeño del municipio en términos de sus gastos en gestión ambiental y la capacidad de recaudar fondos a través del ICMS-E, un instrumento legal que aumenta los ingresos fiscales para los municipios con mejor desempeño ambiental. A partir del análisis de datos provenientes del presupuesto público y las características de los consejos ambientales municipales, se afirma que la existencia de consejos afecta positivamente la gestión ambiental municipal. Los gastos con la función de gestión ambiental y las transferencias ICMS-E tienden a ser mayores en los municipios donde los consejos ambientales están presentes. Esto significa que la participación social, a través de los consejos, afecta positivamente la gestión ambiental municipal y contribuye a mejorar su capacidad financiera.

Palabras clave: Participación pública, Consejos municipales, Políticas ambientales, Brasil. 


\section{INTRODUCTION}

The importance of environmental issues in public policy is increasing in all countries and so too, in a recent trend, is citizen participation in the decision-making and policy-making process. The purpose of this article is to discuss the association between these two trends, examining the case of environmental policies at the municipal level in Brazil.

More specifically, the objective is to analyze whether citizen participation in environmental management in Brazil, through Municipal Environmental Councils, affects policies on the ground, measured in terms of spending on environmental management and the ability to obtain funds from the Ecological ICMS (ICMS-E), a legal instrument that increases tax revenues for municipal governments with a better environmental performance.

The article examines whether public participation in the Councils creates pressure on policy makers that positively affects the proportion of municipal spending that goes to environmental management, with the resulting improvement in environmental conditions boosting the municipality's position in the environmental ranking established by states for the redistribution of the tax revenues raised by the ICMS. This creates a win-win situation in which the increase in the municipal government's financial capacity supports the implementation of public policies for the region and improvement in the population's quality of life.

It should be noted that each of the Brazilian states with ICMS-E legislation has its own criteria for defining the distribution of these tax resources. In the majority of these states, the existence of a Municipal Environmental Council does not affect the value of financial transfers under the ICMS-E.

This article is divided into six sections. The next section describes the Public Policy Councils, their origin and institutional importance, with a focus on the Municipal Environmental Councils. In the third section, the Ecological ICMS is discussed as a mechanism to compensate for or encourage environmental management by Brazilian municipal governments. The data examined in the article are set out in the fourth section. In the fifth section, the results of the research are analyzed using descriptive statistics, confirming the hypothesis that the existence of a Municipal Environmental Council encourages spending on environmental management and promotes the transfer of resources to the municipal government through the ICMS-E. The sixth section presents the conclusions of the research. 


\section{PUBLIC POLICY COUNCILS}

In Brazil, citizen participation in government decisions was institutionalized in 1988 through the Federal Constitution, drawn up during the process of re-democratization. The Federal Constitution (Brasil 1988) includes a series of initiatives that strengthen direct and semi-direct democracy, designed to increase citizens' participation in public management. They include the Public Policy Councils (Article 204 of the Constitution).

In the Public Policy Councils, public authorities and civil society meet on an equal basis to discuss and make decisions in certain fields of public management and policy (health, education, environment, etc.). These participatory bodies are present at the heart of the public administration at the three federal levels (Union, States and Municipalities). Their objective is to produce a more democratic environment for public management. They have duties that include participation in the planning of state policies, budgetary control, the approval of public-private partnerships and the establishment of procedures for the democratization of information and government decisions.

The federative entity that creates each Public Policy Council determines its characteristics, functioning and powers, including their role, scope, number of members and how they are chosen. The Council can be consultative, deliberative, normative, auditory or have a combination of these roles. Regardless of their differences, all Councils serve as a common space for joint discussion between government and civil society about public policies on diverse topics.

Although Public Policy Councils form part of the Federal Constitution of 1988, they were only created in a number of Brazilian municipalities after 1990. Since then, their number has grown significantly because their existence is a condition for financial transfers from the federal government to states and municipal governments and because the idea of a nongovernmental public sphere to permit social participation in political decisions has gained ground (Paula 2005). According to IPEA (2015), in 2013, there were approximately 25,000 Municipal Councils (an average of five councils per municipality) and 350 State Councils, responsible for discussing a wide range of topics, including health, public safety, education and the rights of children and adolescents.

Given the expansion and significance of this democratic management initiative, different authors have studied the Councils' impacts over time (Tatagiba 2002, Vasconcelos, Almeida \& Peixoto 2017), the profile and 
role of their members (Martins et al. 2008, Kezh, Bógus \& Martins 2016) and their ability to influence public policy (Santos \& Gugliano 2015, Avritzer 2011). These studies identified a series of challenges faced by the Councils in seeking to serve as effective democratic spaces. Emphasis should be placed on the need to consolidate a democratic culture in which representatives of civil society are supported by their constituents.

Depending on the way representatives of civil society are selected to participate in the Council, the challenges may also include clientelism and corporatism. As mentioned above, the rules for selecting civil society representatives are established by the Council regulations in each federative entity but, in general, it occurs through nominations or elections by organizations involved in the particular field addresses by the Council.

The Councils still face problems that reduce the effectiveness of participation such as bureaucratic isolation, the difficulty of accessing the information generated by the government and the co-option of councilors by the Municipal Executive (Martins et al. 2008, Dagnino 2002, Azevedo 2016).

Despite these problems, the Public Policy Councils are among the main examples of participatory democracy in Brazil and local governments are considered the administrative political unit that offers the most effective conditions for supporting participation (Martins et al. 2008). The Councils help to democratize decisions, control public policies and make them more transparent. Social participation in the Councils also contributes to the formulation of public policies as in the case of Brazil's Food and Nutrition Security Policy (Zimmermann 2011).

The Councils cannot go beyond the thematic boundaries for which they were established, implying that Environmental Councils must confine themselves to environmental issues. In 2017, Environmental Councils existed in 4,130 municipalities (74\% of the total) and 3,060 of these Councils were active (defined as having held meetings in the 12 months prior to the survey). This percentage is smaller than for Municipal Councils in the fields of health, social assistance, the rights of children and adolescents and education (IBGE 2018). However, in these fields, the existence of a Council is a condition for municipal governments to receive state and federal funds, a requirement that does not apply in the environmental field. The only exceptions to this rule are in the States of Rio de Janeiro, Acre, Piauí and Goiás where the transfer of resources under the legislation of the ICMS-E does require the existence of a Municipal Environmental Council. 
Aydos and Neto (2016) discuss the relationship between the ICMS-E and the political-administrative environmental structures of Brazilian municipalities. They identified a greater presence of Municipal Environmental Councils in cities with more than 100,000 inhabitants and in states with ICMS-E legislation, regardless of whether this requires the creation of a Council as a condition for transfers or not. The ICMS-E is detailed in the next section.

Arruda (2017) emphasizes that the members of Municipal Environmental Councils are predisposed to cooperation, but there are difficulties and resistances, particularly related to the challenges of dealing with private interests at odds with social demands. Strong social representation is, therefore, important. On the other hand, Nunes, Rossato \& Pfitscher (2012) consider that the Environmental Councils are spaces for discussion, the dissemination of information and environmental education and are capable of promoting the construction of citizenship.

The presence of Public Policy Councils in a municipality indicates that civil society can participate in government proposals and decision-making in relation to a given field. Section 5 examines this in greater detail, seeking to verify whether the existence of an Environmental Council can influence budget decision-making, encouraging the municipal government to spend more on environmental management.

\section{ECOLOGICAL ICMS}

The literature provides many examples of how economic instruments for environmental management can be used to influence the behavior of stakeholders in voluntary conservation actions (Kosoy, Corbera \& Brown 2008, Wunder 2013, Bremer, Farley \& Lopez-Carr 2014). One of the successful experiences is the Ecological ICMS (ICMS-E). Under this taxsharing system, included in the legislation of 17 Brazilian states (out of a total of 26), part of the transfers of revenues from the ICMS tax must be based on the municipality's environmental performance, measured according to criteria defined by each state (Castro et al. 2018).

The ICMS (acronym for Tax on the Circulation of Goods and Services) is a state value-added tax regulated by Articles 155 and 158 of the Federal Constitution (Brasil 1988). A quarter of the total amount collected by the state must be transferred to its municipal governments and, out of this, three-quarters must be distributed according to the economic activity generated in the territory of each municipality and the other quarter according to the legislation of the state, which has autonomy to define the 
specific criteria. In states with ICMS-E legislation, part of the transfer of these tax revenues depends on municipalities' environmental performance (Castro et al. 2019).

In Brazil, inequalities in the tax system drive agreements and partnerships between the different spheres of government. In particular, municipal governments find it difficult on their own to raise sufficient resources to implement public policies. States, and especially the Union, play the role of leaders in the search for coordination between different federative entities, mainly due to their greater financial capacity. Moreover, dependence on money transfers and financing can result in subordinate relationships between government entities that should negotiate independently (Arretche 2006). Leadership can also be used to promote competition between municipal governments in order to align their interdependent activities with common goals, for example, by establishing criteria for the redistribution of money transfers, as in the ICMS-E (Castro et al. 2018).

The ICMS-E can be understood as a federative coordination mechanism since it aligns the actions of the municipal governments with the state's interest. Depending on the characteristics of the state legislation, this mechanism uses the idea of compensation or positive competition between municipalities for more state funds, based on meeting the criteria stipulated by the state.

There is a wide range of environmental criteria for the distribution of the ICMS-E quota. They include the existence of protected areas, sources of water supply, systems for collecting and recycling waste, the characteristics and quality of environmental management and the existence of policies for environmental reforestation or forest fire control as well as the existence of a Municipal Environmental Council.

The percentage of the distributed quota of ICMS-E and how the distribution is calculated in each state differ significantly, with proposals to create performance ratings based on the quality or importance of the areas to be conserved. In some cases, these calculations are difficult to understand and lack of transparency in accounting disclosure, the criteria and the value of transfers does not favor the involvement of municipalities in this policy. A lack of awareness of the ICMS-E on the part of municipal managers is a problem noted in various studies (Ribeiro et al. 2013, Uhlmann, Rossato, \& Pfitscher 2010, Moreira 2004).

As a policy coordination mechanism, information about the ICMS-E needs to be disseminated in order to guarantee municipal engagement. 
If a state does not provide ample information about the ICMS-E, its parameters, calculations and transfers, municipalities will have less incentive to comply with the stipulated environmental criteria, reducing the proposal's effectiveness. Therefore, Environmental Public Councils have a strategic role in the discussion and dissemination of this political mechanism.

Castro et al. (2018) observed growth over time in the number of states that implemented the ICMS-E, suggesting that it is a successful policy: states are able to coordinate actions to improve environmental quality without increasing their spending. This result was corroborated by a linear regression analysis that demonstrated statistically that the existence of the ICMS-E legislation induces the creation of protected areas under municipal management.

In the next sections, data from Brazilian municipalities are examined to evaluate whether social participation through Councils is associated with the municipality's environmental performance through increased spending on environmental management. Another point examined is whether the presence of the Councils results in greater resources obtained through the ICMS-E.

\section{DATA COLLECTION AND METHODOLOGY}

For the empirical analysis, a database was built from the following primary sources:

1. Municipal financial database, including total revenues, the amounts received through the ICMS-E, budget spending on environmental management and total spending in 2012-2016, with monetary values adjusted to 2016 prices $^{1}$. This period was chosen for reasons of data availability. Sources: Brazilian Public Sector Accounting and Tax Information System (SICONFI) ${ }^{2}$ and State Secretariats for the Environment and Finance, using searches of their websites and direct contact (phone calls and e-mail) ${ }^{3}$.

2. Information on the existence of Municipal Environmental Councils and Municipal Environmental Funds was obtained from the

1 The average exchange rate in 2016 was $\mathrm{R} \$ 3.49 / \mathrm{US} \$$.

2 https://siconfi.tesouro.gov.br/siconfi/index.jsf.

3 Methodological procedures described in Castro et al. (2019). 
Municipal Basic Information Survey (MUNIC) for 2017, carried out by the Brazilian Institute of Geography and Statistics (IBGE 2018). The MUNIC database also indicates the year the Council was created, the nature of its operation, whether it has the financial resources to promote its actions and whether it is responsible for the management of environmental funds.

Information on revenues and municipal spending on the "Environmental Management Function" was obtained from the SICONFI database for which a methodological description is available in the Technical Budget Manual (Brazil 2017). Spending on the Environmental Management Function includes all the corresponding programs and actions, with the wages and social security contributions of civil servants and the following sub-functions: environmental preservation and conservation, environmental control, the recovery of degraded areas, water resources and meteorology.

Total municipal revenues, including transfers, were used in the analysis, rather than only municipal tax revenues. Most Brazilian municipal governments have low collection capacity and depend heavily on federal and state transfers (Gomes \& MacDowell 2000). According to FIRJAN (2017), $81.7 \%$ of Brazilian cities were unable to generate up to $20 \%$ of their revenues from their own tax collection in 2016. In addition, the most important element for environmental spending by municipal governments is the ability to finance it, regardless of whether the resources come from their own collection or from transfers.

The MUNIC survey periodically presents detailed information about the structure, dynamics and operations of public municipal institutions and their different sectors, in which city hall is the survey's main informant (IBGE 2018). This survey provides a range of information about public municipal management, including the legislation and planning instruments that exist in this administrative sphere, especially those established in the Statute of the Cities, covering all Brazil's 5,570 municipal governments.

\section{RESULTS}

Using the databases described in the previous section, it was possible to examine the possible association between the existence of Municipal Environmental Councils, municipal governments' average spending on environmental management and the volume of transfers received through the ICMS-E. The data were expressed as average values for the variables in constant Reais (R\$) for 2016. 
Table 1 shows the crossing of information organized in two ways: spending on the "Environmental Management Function" (environmental expenditure) as a proportion of total spending and the budgetary resources received from the ICMS-E as a proportion of total municipal revenues. The municipalities that have a Municipal Environmental Council were also categorized based on whether the Councils manage Municipal Environmental Funds, whether they have resources available to promote their actions and how long the Council has been in existence.

Table 1: Relative and absolute means of expenditure on environmental management and ICMS-E collected according to the existence of a Municipal Environmental Council

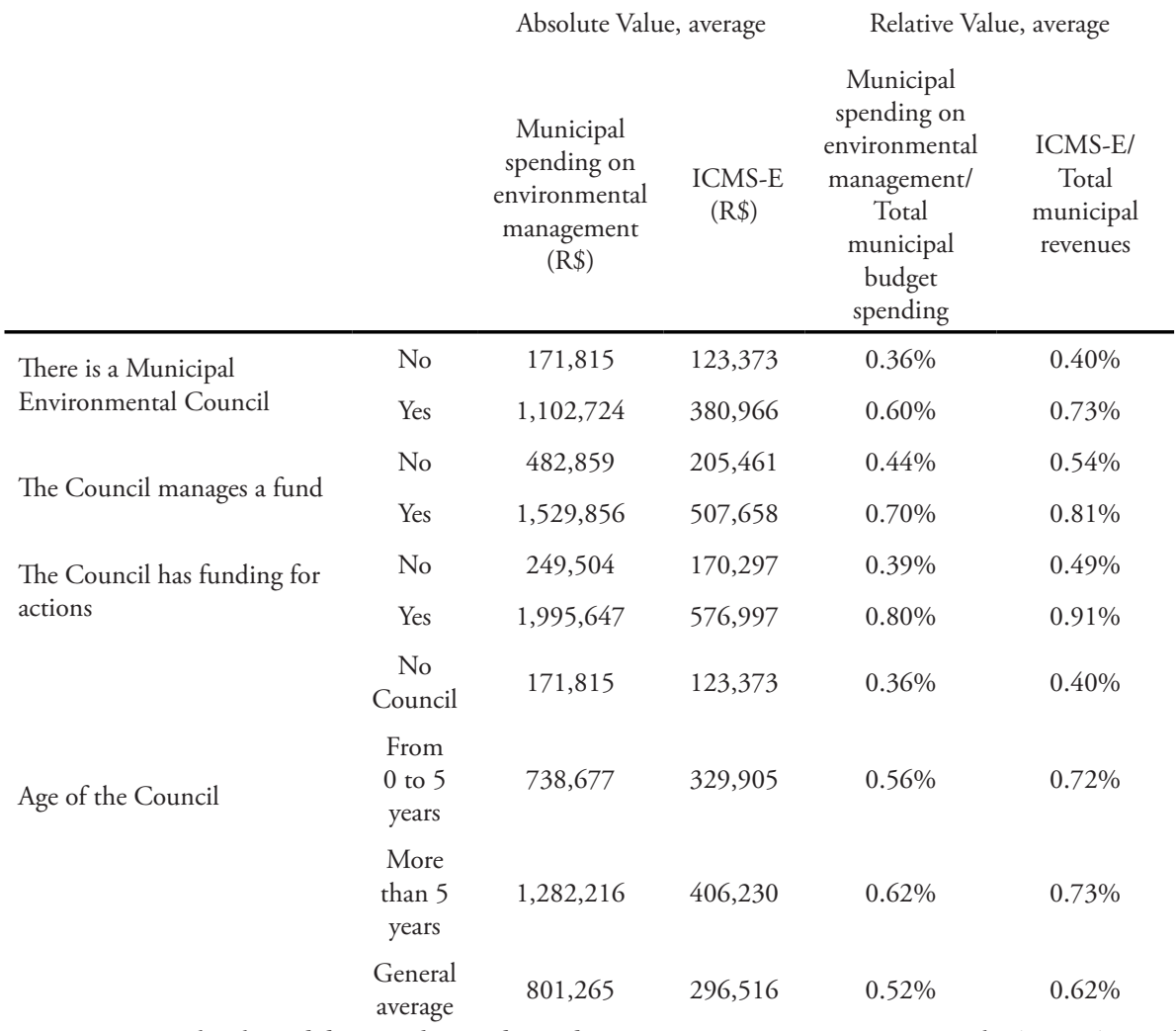

Source: Calculated by authors, based on SICONFI, Castro et al. (2018) and IBGE (2018).

The results show that spending on environmental management and the revenues obtained from the ICMS-E are higher in municipalities where there is a Municipal Environmental Council. 
In the first case, average expenditure on environmental management is higher in municipalities with a Council $(0.60 \%$ of the total) than in those without a Council (average of $0.36 \%$ ). Similarly, when the Environmental Council is responsible for influencing spending through the administration of Municipal Funds, average municipal spending on the Environmental Management Function is higher.

The same relationship holds for funds obtained through the ICMS-E: municipalities with an Environmental Council obtain more tax transfers than municipalities without a Council. This relationship is greater when Council boards manage funds or when they have their own resources for their actions. In other words, the Council's ability to manage funds and the existence of financial resources to promote actions planned by the Council are variables that affect spending on environmental management (absolute or relative) and collection of the ICMS-E.

Municipalities with an Environmental Council spend an average of $\mathrm{R}$ \$ 1.1 million per year on environmental management and collect R\$ 381,000 through the ICMS-E. These amounts are well above the average spending of $\mathrm{R} \$ 172,000$ in municipalities without a Council and $\mathrm{R} \$$ 123,000 collected from the ICMS-E.

When Environmental Councils are able to mobilize financial resources for their actions, these differences are even greater. In municipalities where the Council has its own financial resources, average annual spending on Environmental Management Function reaches R $\$ 2.0$ million while the amount raised through the ICMS-E reaches $\mathrm{R} \$ 577,000$. By contrast, for municipalities where the Environmental Council has no financial resources, the figures are $\mathrm{R} \$ 250,000$ and $\mathrm{R} \$ 170,000$, respectively.

Municipalities with Councils that manage environmental funds spend an average $0.70 \%$ of the municipal budget on environmental management. When the Council has its own resources to spend, this increases to $0.80 \%$. These figures are higher than the average for municipalities with a Council that does not have its own resources or participate in the management of resources $(0.44 \%$ and $0.39 \%$, respectively).

The same type of association is observed for amounts received through the ICMS-E. In municipalities with an Environmental Council that manages financial resources, the ICMS-E accounts for an average $0.81 \%$ of total municipal revenues and this rises to $0.91 \%$ when the Council has its own resources. These numbers are well above the average ICMS-E transfer in municipalities where the Council does not manage resources $(0.54 \%)$ 
or does not have its own resources $(0.49 \%)$.

The length of time a Council has been in existence also affects spending on municipal management and revenues received from the ICMS-E. In municipalities with older Councils (in existence for more than five years), average annual environmental expenditure is $\mathrm{R} \$ 1.3$ million $(0.62 \%$ of total budget spending). This drops to $\mathrm{R} \$ 739,000$ ( $0.56 \%$ of total spending) in municipalities where the Council is five years old or less.

These results are maintained when the data are aggregated by municipalities in states with and without ICMS-E legislation (Table 2). Average expenditure on environmental management (in monetary values and as a percentage of the total budget) is always greater in municipalities in states with ICMS-E legislation.

Table 2: Average spending on environmental expenditure and ICMS-E collected according to the existence of a Municipal Environmental Council in municipalities with and without ICMS-E legislation

\begin{tabular}{|c|c|c|c|c|}
\hline & & & $\begin{array}{c}\text { Municipal } \\
\text { spending on } \\
\text { environmental } \\
\text { management } \\
\text { (R\$) }\end{array}$ & $\begin{array}{c}\text { Municipal spending } \\
\text { on environmental } \\
\text { management/ Total } \\
\text { municipal budget } \\
\text { spending }\end{array}$ \\
\hline \multirow{6}{*}{$\begin{array}{l}\text { Without } \\
\text { ICMS-E }\end{array}$} & \multirow{2}{*}{$\begin{array}{l}\text { There is a Municipal Environmental } \\
\text { Council }\end{array}$} & No & 88,802 & $0.22 \%$ \\
\hline & & Yes & 491,506 & $0.33 \%$ \\
\hline & \multirow{2}{*}{ The Council manages a fund } & No & 194,586 & $0.24 \%$ \\
\hline & & Yes & 679,769 & $0.43 \%$ \\
\hline & \multirow{2}{*}{ The Council has funding for actions } & No & 133,256 & $0.23 \%$ \\
\hline & & Yes & 945,726 & $0.47 \%$ \\
\hline \multirow{9}{*}{$\begin{array}{l}\text { With } \\
\text { ICMS-E }\end{array}$} & $\begin{array}{l}\text { Average for municipalities without } \\
\text { ICMS-E }\end{array}$ & & 299,833 & $0,28 \%$ \\
\hline & \multirow{2}{*}{$\begin{array}{l}\text { There is a Municipal Environmental } \\
\text { Council }\end{array}$} & No & 292,884 & $0.46 \%$ \\
\hline & & Yes & $1,379,391$ & $0.70 \%$ \\
\hline & \multirow{2}{*}{ The Council manages a fund } & No & 719,728 & $0.56 \%$ \\
\hline & & Yes & $1,898,989$ & $0.81 \%$ \\
\hline & \multirow{2}{*}{ The Council has funding for actions } & No & 355,167 & $0.48 \%$ \\
\hline & & Yes & $2,406,223$ & $0.92 \%$ \\
\hline & $\begin{array}{l}\text { Average for municipalities with } \\
\text { ICMS-E }\end{array}$ & & $1,131,548$ & $0,65 \%$ \\
\hline & General average & & 801,265 & $0.52 \%$ \\
\hline
\end{tabular}

Source: Calculated by authors, based on SICONFI, Castro et al. (2018) and IBGE (2018). 
Municipal Environmental Councils can play more than one role - for example, a Council can be advisory and deliberative at the same time. Table 3 presents the results for average environmental spending and transfers from the ICMS-E according to the duties of the Municipal Environmental Council. In this case, the differences between the relative and absolute averages according to the different types of tasks of the Council are small, with a slight trend towards higher spending on environmental management when the Council has a deliberative character. In the case of revenues from the ICMS-E, there is no clear pattern of difference in the variables analyzed.

Table 3: Relative and absolute averages of expenditure on environmental management and ICMS-E collected according to the character of the Municipal Environmental Council

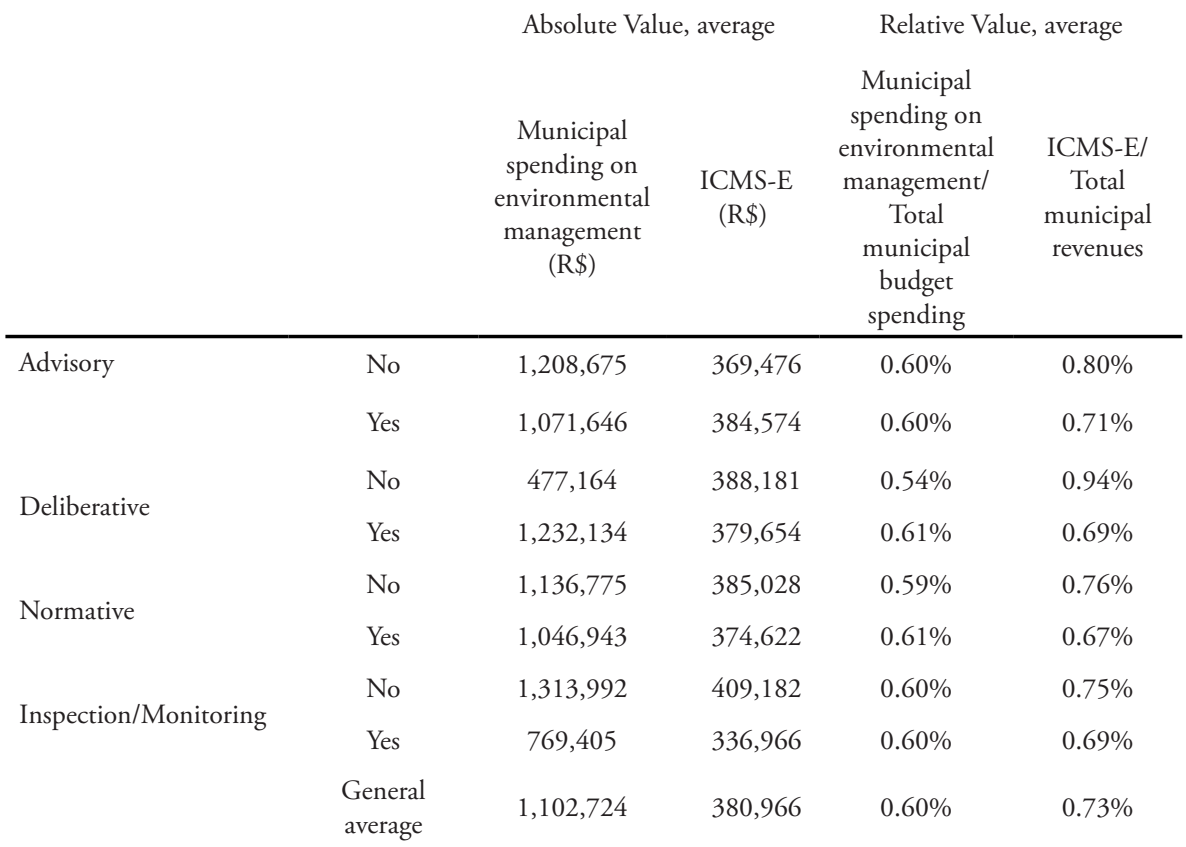

Source: Calculated by authors, based on SICONFI, Castro et al. (2018) and IBGE (2018).

In summary, the empirical results confirm the hypotheses indicated at the beginning of this study: citizen participation, measured as the existence of Municipal Environmental Councils, positively affects the budget allocated to environmental management and the ability to obtain funds through the ICMS-E. 
In an additional result, spending on environmental management and the resources obtained through the ICMS-E are higher if the Environmental Council has the power to decide on the management of financial resources. This suggests that the effect of Municipal Environmental Councils is greatest when they have power over financial decisions, whether through participation in the management of funds or the availability of their own resources to spend.

\section{FINAL CONSIDERATIONS}

The purpose of this article was to verify whether citizen participation affects the performance of Brazilian municipal governments in terms of their environmental policies. An empirical study analyzed the influence of social participation, as represented by the existence or not of a Municipal Environmental Council, on the capacity to impact public policies, measured by municipal environmental spending and the financial transfer from states to municipal governments based on the ICMS-E.

The results show that, in municipalities where there is an Environmental Council, average spending on environmental management tends to increase. In addition, the presence of an Environmental Council tends to contribute positively to the municipality's fulfillment of the environmental criteria established by the ICMS-E legislation and, therefore, the receipt of larger financial transfers.

The amount spent on environmental management and compliance with the ICMS-E criteria are imperfect indicators of the quality or quantity of environmental policies and the mere existence of a Municipal Environmental Council is a weak proxy for citizen participation in this field. Despite these limitations, the results clearly support the hypothesis that citizen involvement in public policy decision-making puts pressure on local governments to pay more attention to environmental management.

Another interesting result is that the existence of ICMS-E legislation seems to be positively associated with the existence of Municipal Environmental Councils. This is an indication that these laws can induce more active environmental action on the part of municipalities.

Public Policy Councils still face challenges in becoming institutional spaces that effectively promote wider social participation. In relation to the Environmental Councils, the literature emphasizes that these spaces suffer from the domination of private interests over social ones. However, the Councils are also seen as spaces for democratic experimentation of 
unprecedented scope in Brazil as regards the institutionalization of society's participation in public decisions.

This suggests that social participation may positively contribute to environmental management, expanding its capacity to implement public policies by bolstering greater financing for the area. These questions deserve attention in future research on this subject. 


\section{REFERENCES}

Arretche, M. (2006). Federalismo e políticas sociais no Brasil: Problemas de coordenação e autonomia. In Saraiva, E. and Ferrarezi, E. (Eds.), Coletânea de politicas públicas: volume 2. Brasília, DF: ENAP.

Arruda, I. M. (2017). Representação política e participação social no diálogo entre sociedade e estado na perspectiva da sociedade civil: um estudo do Conselho Municipal de Meio Ambiente da cidade do Rio de Janeiro. Dissertação de Mestrado (Administração), Universidade Federal Rural do Rio de Janeiro, Seropédica, RJ, Brasil.

Avritzer, L. (2011). A qualidade da democracia e a questão da efetividade da participação: mapeando o debate. In Pires, R. R. C. (Eds.), Efetividade das instituiçóes participativas no Brasil: estratégias de avaliação. Brasília, DF: IPEA.

Aydos, L. R. \& Neto, L. F. F. (2016). Estudo da correlação entre ICMS Ecológico e estrutura político-administrativa ambiental nos municípios brasileiros. Acta Scientiarum. Human and Social Sciences, 38 (2), 131141.

Azevedo, N. L. D. (2016). Por que os Conselhos não funcionam? O diagnóstico O'Donnell. Anais do $40^{\circ}$ Encontro Anual da Associação Nacional de Pós-Graduação e Pesquisa em Ciências Sociais, Caxambu, MG, Brasil.

Brasil (1988). Constituição da República Federativa do Brasil. Brasília, DF: Senado Federal: Centro Gráfico.

Bremer, L. L., Farley, K. A. \& Lopez-Carr, D. (2014). What factors influence participation in payment for ecosystem services programs? An evaluation of Ecuador's SocioPáramo program. Land Use Policy, 36, 122-133.

Castro, B. S., Correa, M. G. C., Costa, D. S., Costa, L. A. N., Medeiros, R. \& Young, C. E. F. (2018). Geração de receitas tributárias municipais. In Young, C. E. F. and Medeiros, R. (Eds.), Quanto vale o verde: a importância econômica das Unidades de Conservaçáo brasileiras. Rio de Janeiro: Conservação Internacional. 
Castro, B. S., Young, C. E. F., Costa, L. A. N., Costa, D. S. (2019) O ICMS Ecológico como uma política de incentivo dos gastos ambientais municipais. Desenvolvimento em Debate, 7 (1),181-199.

Dagnino, E. (2002). Sociedade civil e espaços públicos e a construção democrática no Brasil: Limites e possibilidades. In Dagnino, E. (Eds.), Sociedade civil e espaços públicos no Brasil, São Paulo: Paz e Terra.

FIRJAN (2017). IFGF - Índice Firjan de gestão fiscal 2017: Ano base 2016. Recorte municipal abrangência nacional. Elaboração do estudo GEE - Gerência de Estudos Econômicos. Agosto/2017. Available at http://publicacoes.firjan.org.br/ifgf/2017/files/assets/basichtml/page-1.html [01-12-2019].

Gomes, G. M. \& Mac Dowell, M. C. (2000). Descentralizaçâo política, federalismo fiscal e criação de municípios: o que é mau para o econômico nem sempre é bom para o social. [Texto para discussão, No 706]. Brasília, DF: IPEA.

Instituto Brasileiro de Geografia e Estatistica (IBGE) (2018). Perfil dos municípios brasileiros: 2018. Rio de Janeiro: IBGE-Coordenação de População e Indicadores Sociais.

Instituto de Pesquisa Econômica Aplicada (IPEA) (2015). Instituto de pesquisa centraliza dados de conselhos municipais e estaduais de 1999 a 2013. Participação em Foco. Available at https://www.ipea.gov.br/ participacao/destaques/1184-ibge [01-12-2019].

Kezh, N. H. P., Bógus, C. M. \& Martins, C. L. (2016). Entraves à participação social dos representantes dos trabalhadores no conselho municipal de saúde. Saúde e Sociedade, 25 (4), 950-963.

Kosoy, N., Corbera, E. \& Brown, K. (2008). Participation in payments for ecosystem services: case studies from the Lacandon rainforest, Mexico. Geoforum, 39 (6), 2073-2083.

Martins, M. F., Martins, S., Oliveira, A. R. de, \& Soares, J. B. (2008). Conselhos municipais de políticas públicas: uma análise exploratoria. Revista do Serviço Público, 59 (2), 151-185.

Moreira, A. D. (2004). A gestão do ICMS ecológico em Mato Grosso do Sul. Dissertação de Mestrado, Universidade para o Desenvolvimento do Estado e da Regiáo do Pantanal, Campo Grande, MS, Brasil. 
Nunes, M. R., Philippi Jr, A. \& Fernandes, V. (2012). A atuação de conselhos do meio ambiente na gestáo ambiental local. Saúde $e$ Sociedade, 21, 48-60.

Paula, A. P. P. (2005). Por uma nova gestão pública: Limites e potencialidades da experiência contemporânea. Rio de Janeiro: Editora FGV.

Ribeiro, C. D. A., Rossato, M. V., Guse, J. C., Freitas, L. A. R. \& Dorr, A. C. (2013). ICMS Ecológico: uma abordagem à gestão ambiental nos municípios do Rio Grande do Sul. Revista Sociais e Humanas, 26(2), 363-383.

Santos, P. R. D. \& Gugliano, A. A. (2015). Efetividade das políticas participativas no governo brasileiro: o Conselho de Desenvolvimento Econômico e Social. Revista de Sociologia e Política, 23 (56), 3-19.

Tatagiba, L. (2002). Os conselhos gestores e a democratização das políticas públicas no Brasil, In Dagnino, E. (Eds.), Sociedade civil e espaços públicos no Brasil, São Paulo: Paz e Terra.

Uhlmann, V. O., Rossato, M. V. \& Pfitscher, E. D. (2010). Conhecimento dos gestores públicos sobre o instrumento de política pública ICMS ecológico nos municípios da quarta colônia de imigração italiana do RS. Enfoque: Reflexão Contábil, 29 (2), 83-102.

Vasconcelos, M. C. C., Almeida, N. N. \& Peixoto, L. F. (2017). Conselho Estadual de Educação do Rio de Janeiro: heranças, marcos legais e limites políticos de um órgão do Estado. Ensaio: Avaliação e Políticas Públicas em Educação, 25 (96), 701-720.

Wunder, S. (2013). When payments for environmental services will work for conservation. Conservation Letters, 6 (4), 230-237.

Zimmermann, S. A. (2011). A pauta do povo e o povo em pauta: as Conferências Nacionais de Segurança Alimentar e Nutricional, Brasil - Democracia, participação e decisão política. Tese de doutorado, Universidade Federal Rural do Rio de Janeiro, Seropédica, RJ, Brasil.

Recibido: 05-02-2019

Aceptación de la versión final: 29-12-2019 